\title{
RECRYSTALLIZATION BEHAVIOUR OF A NICKEL-BASED SUPERALLOY
}

\author{
OBNAŠANJE SUPERZLITINE NA OSNOVI NIKLJA PRI \\ REKRISTALIZACIJI
}

\author{
Pavel Podany, Zbysek Novy, Jaromir Dlouhy \\ COMTES FHT, Prumyslova 995, 33441 Dobrany, Czech Republic \\ pavel.podany@comtesfht.cz \\ Prejem rokopisa - received: 2014-08-01; sprejem za objavo - accepted for publication: 2015-04-16
}

doi: $10.17222 /$ mit.2014.163

\begin{abstract}
The thermomechanical processing of a nickel-based superalloy is the way to considerably influence the grain size. A uniform coarse-grain size increases the creep strength and the crack-growth resistance. In this work, the processing for achieving a uniform recrystallized-grain structure with a variation in the thermomechanical parameters is investigated.

The MoNiCr alloy is intended for modern designs of nuclear reactors, in which molten fluoride salts are used as the coolants in the primary and/or secondary circuit. It represents a material alternative with a high corrosion resistance in the area of fluoride salts and it has very good creep properties in the temperature range of $650-750{ }^{\circ} \mathrm{C}$ as well.

The manufacture of vessels and fittings from the MoNiCr alloy requires the mastering of the technology for forming this high-alloyed material. The key step seems to be the transition of the cast state of the material to the state of a cast recrystallized microstructure with homogenous fine grains. A particular stress condition is, besides the temperature, very important during hot forming. Nickel alloys are able to accept a significantly higher deformation level if the compressive stress prevails.

A forming process involving the compression state of stress increases the probability that the material will reach, without failure, a level of deformation that allows recovery and recrystallization processes. A particular deformation process was carried out on a physical simulator. The preceding cold deformation essentially accelerates the recrystallization process of a deformed cast structure.

Keywords: recrystallization, nickel alloys, physical simulation
\end{abstract}

Termomehanska obdelava superzlitine na osnovi niklja je način, s katerim lahko močno vplivamo na velikost kristalnih zrn. Enakomerna velikost velikih zrn povečuje odpornost na lezenje in ovira rast razpok. V tem delu je s spreminjanjem parametrov termomehanske predelave preiskovana predelava za doseganje enakomerne rekristalizirane mikrostrukture.

Zlitina MoNiCr je namenjena modernemu konceptu nuklearnih reaktorjev, v katerih se uporablja staljene fluoridne soli, kot sredstvo za hlajenje v primarnem in/ali sekundarnem tokokrogu. Predstavlja alternativni material z visoko korozijsko odpornostjo v področju fluoridnih soli in ima hkrati zelo dobro odpornost na lezenje v temperaturnem področju $650-750{ }^{\circ} \mathrm{C}$.

Izdelava posod in prirobnic iz zlitine MoNiCr zahteva obvladovanje tehnologije preoblikovanja tega visoko legiranega materiala. Ključni moment izgleda je preoblikovanje litega stanja materiala do stanja rekristalizirane mikrostrukture s homogenimi, drobnimi zrni. Pri vročem preoblikovanju je poleg temperature pomembno tudi stanje napetosti. Nikljeve zlitine so sposobne veliko večje deformacije, če prevladujejo tlačne napetosti.

Preoblikovanje s tlačnimi napetostmi povečuje verjetnost, da bo material brez porušitve dosegel tak nivo deformacije, ki omogoča procese poprave in rekristalizacije. Proces deformacije je bil izvršen na fizikalnem simulatorju. Nadaljnja hladna deformacija občutno pospeši proces rekristalizacije deformirane lite strukture.

Ključne besede: rekristalizacija, nikljeve zlitine, fizikalna simulacija

\section{INTRODUCTION}

Superalloys are nickel-, iron-nickel-, and cobaltbased alloys generally used at temperatures above about $540{ }^{\circ} \mathrm{C}$. The alloys that can be used even at higher temperatures are continuously investigated thanks to their excellent mechanical and corrosion properties. ${ }^{1}$ The iron-nickel-based superalloys form an extension of the stainless-steel technology and are generally wrought. A large number of alloys were invented and studied; many were patented. However, many alloys were winnowed down over the years; only a few are extensively used. ${ }^{2}$ Due to their excellent creep resistance, the nickel-based superalloys are used in the power industry, especially for power engineering. The current nuclear-power engineering is mostly represented by the light water nuclear reactor that uses low-enriched uranium in the form of uranium dioxide as its fuel. However, the current use of the uranium raw material is low, in most cases it ranges between $3 \%$ and $5 \%$. A limited number of reactors use mixed uranium-plutonium fuel that increases the primary use of the uranium raw material. The research of the fourth-generation reactor system deals with the way of how to prevent a non-economical use of uranium. ${ }^{3}$

The fourth generation of reactors is generally divided into two types: thermal and fast reactors. The thermal reactors use a moderator to slow down the neutrons emitted by fission, making them more likely to be captured by the fuel. A fast reactor directly uses the fast neutrons emitted by fission, without a moderation. These new reactors are designed with the following objectives in mind: 3,4

- Enhanced nuclear-reactor safety

- Increase in the nuclear-reactor energy efficiency 
- Closure of the nuclear-reactor fuel cycle

- Reduction in the fuel-radioactivity level

- Disposal of the used fuel

It appears that the waste management is the major concern regarding the existing once-through cycle because of the limited availability of the repository space worldwide. Closed fuel cycles of recycling reactors allow some of the fuel to be reused. An improvement in the reactor performance can be achieved if the thermal and fast reactors are operated in a coupled mode. An increase in the fuel burnup of the thermal reactors can improve the management of the produced actinides by burning them in situ. With a transmutation, the relative toxicity of the radioactive waste decreases considerably (Figure 1).

An increase in the nuclear-power-plant energy efficiency is possible by increasing the output coolant temperature in the reactor. This can be achieved if a coolant other than water is used. Sodium, lead, gases, supercritical water and other media are under consideration. One of the concepts of the fourth-generation reactors is a molten-salt reactor where molten fluoride salt is considered for the primary and also for the secondary circuit. The main advantage of this reactor is a high efficiency (a high level of the nuclear-fuel usage), but the main disadvantage is the environment of the molten fluoride salt with a temperature of $700-800{ }^{\circ} \mathrm{C}$. A suitable material for fittings and vessels must have an extreme corrosive and creep resistance in this environment. It is, nevertheless, necessary to make moulded plates and pipes that must be bent and hermetically joined together - they must be welded to the shape of the final fittings. The formation of semi-finished products from cast ingot is one of the technologically most complicated operations during the manufacture of vessels and fittings.

Many studies stated that nickel-based superalloys with high Mo and low Cr contents are generally superior with respect to the high-temperature corrosion resistance in fluorine environments. ${ }^{5}$

The main microstructure parameter that affects the mechanical properties is the grain size. It greatly influences the strength, the creep, the fatigue-crack initiation

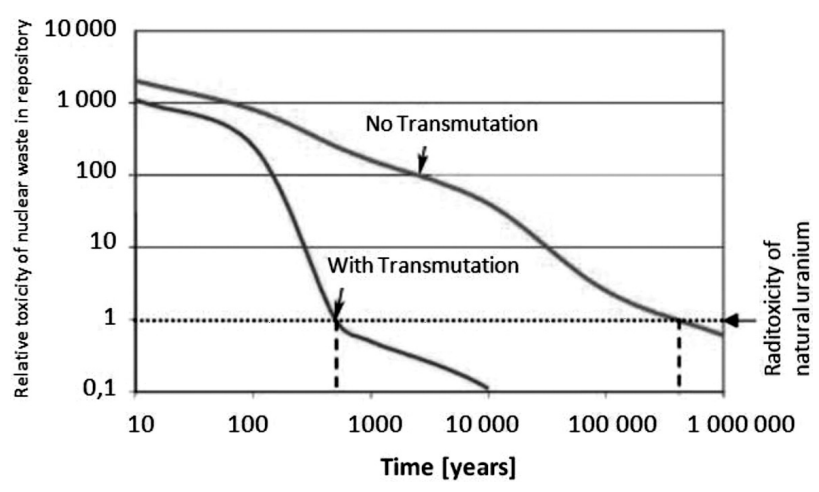

Figure 1: Relative toxicity of the nuclear waste in repository ${ }^{4}$ Slika 1: Relativna toksičnost nuklearnih odpadkov na odlagališču ${ }^{4}$ and the growth rate. A uniform coarse-grain size increases the creep strength, the crack-growth resistance and the ductility. On the contrary, a uniform fine-grain size provides a high low-cycle fatigue life and high tensile and yield strengths. ${ }^{6}$

Usually the microstructure of a nickel superalloy after hot working consists of large and fine grains and is not uniform. Irrespective of whether the microstructure is coarse grained or fine grained it should be uniform for further annealing processing. Previous studies found that hot working followed by cold working and then by the annealing process is the best way to achieve a uniform recrystallized microstructure. ${ }^{7}$

The inability of the nickel-based superalloys to dynamically recrystallize during forging leads to difficulties during the forging at the highest temperatures close to the temperature of solidus. Even more, such high temperatures can lead to hot cracking on grain boundaries. This can be caused partially by the presence of low-melting impurities on the grain boundaries and also by the oxidation, which occurs much faster through the grain boundaries than within the grains. High-temperature oxidation is much promoted by the main solid-solution strengthening element - molybdenum. Therefore, the forging temperature has to be kept in the interval below the hot cracking and above the point that ensures dynamic recrystallization.

The strain rate is the second important parameter of forming. A high strain rate does not bring enough time for "self-healing" processes in the crystal lattice and usually strengthening takes place in the microstructure. This also leads to cracking during forming.

\section{EXPERIMENT DESCRIPTION}

An experiment was carried on the MoNiCr nickel superalloy, developed by COMTES FHT Inc. regarding its application in molten-salt reactor circuits. The chemical composition of this alloy is shown in Table $\mathbf{1 .}$

Table 1: Chemical composition of the experimental alloy in mass fractions $(w / \%)$

Tabela 1: Kemijska sestava preizkusnih zlitin v masnih deležih (w/\%)

\begin{tabular}{|c|c|c|c|c|c|c|c|c|c|}
\hline $\begin{array}{c}\text { Ele- } \\
\text { ment }\end{array}$ & Mo & $\mathrm{Cr}$ & $\mathrm{Ti}$ & $\mathrm{Fe}$ & $\mathrm{Mn}$ & $\mathrm{Nb}$ & $\mathrm{Al}$ & $\mathrm{W}$ & $\mathrm{Ni}$ \\
\hline$w / \%$ & 15.81 & 6.82 & 0.03 & 2.32 & 0.04 & 0.01 & 0.26 & 0.06 & base \\
\hline
\end{tabular}

The experiment was focused on an evaluation of the influences of various thermomechanical processes on the behaviour of the processed samples and their microstructures. At first, an evaluation of the strain-deformation characteristics of the samples made from the material in the as-cast state was performed. A similar evaluation of the strain-deformation characteristics was also made on the samples in the as-cast state, with a preceding hot deformation (while alternating the strain) (Figure 2).

Further experiment consisted of the following steps: 


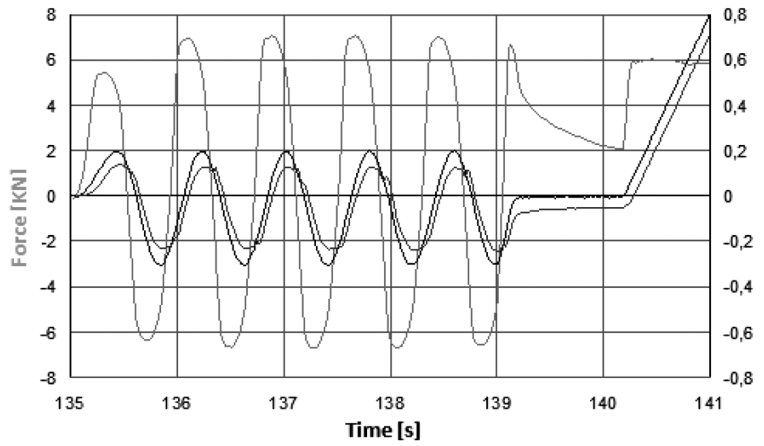

Figure 2: Example of cyclic heat deformation prior to the heat-tensile test $-10{ }^{\circ} \mathrm{C} / \mathrm{s}$ at $1200{ }^{\circ} \mathrm{C}, 15 \mathrm{~s}, 10 \mathrm{~mm} \times 0.5 \mathrm{~mm}, 1 \mathrm{~mm} / \mathrm{s}$

Slika 2: Primer ciklične toplotne deformacije pred vročim nateznim preizkusom $-10{ }^{\circ} \mathrm{C} / \mathrm{s}$ pri $1200{ }^{\circ} \mathrm{C}, 15 \mathrm{~s}, 10 \mathrm{~mm} \times 0,5 \mathrm{~mm}, 1 \mathrm{~mm} / \mathrm{s}$

- Evaluation of the influence of thermomechanical processing (heat deformation) on recrystallization

- Evaluation of the influence of cold deformation on recrystallization.

A strain-deformation characterisation and thermomechanical processing were carried out on the samples whose shape is represented on Figure 3. These samples were tested on a simulator of heat-deformation cycles (Figure 3). This simulator was used in the previous studies for similar purposes. ${ }^{8}$ In the device, the body of a sample is heated by resistance heating to the controlled temperature. In the case of the experimental focus on the evaluation of the thermomechanical processing, a sample is loaded with cycles of tensile and compression deformation. Each partial compressive deformation was higher than the preceding tensile deformation. The total logarithmic degree of deformation for a sample was approximately $0.5-2.5$.

In the case of the experimental focus on the evaluation of cold forming, cold deformation preceded hightemperature deformation - upsetting. Table 2 shows an overview of the performed ways of the treatment.

After the thermomechanical processing, all the samples were cut in the longitudinal direction and they

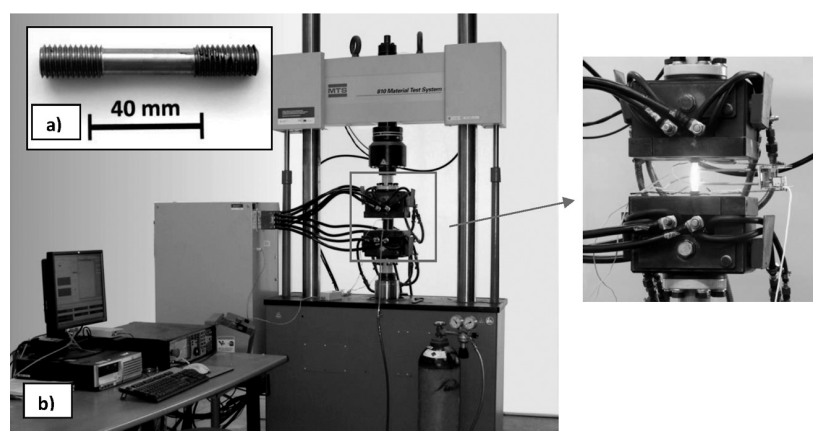

Figure 3: a) Shape of an experimental sample, b) simulator of heat-deformation cycles - servo-hydraulic mechanical testing system MTS complemented by resistance heating

Slika 3: a) Oblika preizkušanca, b) simulator toplotnih deformacijskih ciklov - servo hidravlični mehanski preizkusni sistem MTS, dopolnjen z uporovnim ogrevanjem underwent the standard metallographic preparation (grinding and subsequent polishing). The microstructure was revealed by etching in Marble's reagent and documented on a Nikon light microscope. An image analysis of the recrystallized-grain fraction was performed by means of the NIS-Elements software.

Table 2: Processing of the samples with cold deformation and the subsequent cyclic hot deformation

Tabela 2: Obdelava vzorcev s hladno deformacijo, ki ji je sledila vroča ciklična deformacija

\begin{tabular}{|c|c|c|c|c|}
\hline \multirow{2}{*}{ Embedded deformation } & \multicolumn{3}{|c|}{ Hot Deformation at $1200{ }^{\circ} \mathrm{C}$} \\
\cline { 2 - 5 } & 0.3 & 0.7 & 1.1 \\
\hline $\begin{array}{c}\text { Cold Deformation } \\
\begin{array}{c}\text { (at room } \\
\text { temperature) }\end{array}\end{array}$ & 0.05 & $\begin{array}{c}\text { CD0.05- } \\
\text { HD0.3 }\end{array}$ & $\begin{array}{c}\text { CD0.05- } \\
\text { HD0.7 }\end{array}$ & $\begin{array}{c}\text { CD0.05- } \\
\text { HD1.1 }\end{array}$ \\
\cline { 2 - 5 } & 0.25 & $\begin{array}{c}\text { CD0.25- } \\
\text { HD0.3 }\end{array}$ & $\begin{array}{c}\text { CD0.25- } \\
\text { HD0.7 }\end{array}$ & $\begin{array}{c}\text { CD0.25- } \\
\text { HD1.1 }\end{array}$ \\
\hline
\end{tabular}

\section{RESULTS AND DISCUSSION}

\subsection{Strain-deformation characteristics of the as-cast state}

The tensile test was made on the samples in a temperature range of $1050-1250{ }^{\circ} \mathrm{C}$. As they were in the cast state, the ductility was very low up to the breaking limit of Ag (Figure 4). Even with the cyclic deformation prior to the tensile test, it did not reach the value sufficient for the development of a massive recrystallization. Figure 5 shows the microstructure near the fracture of a sample treated in this way at $1200{ }^{\circ} \mathrm{C}$. Before the tensile test, the sample was loaded with the preceding hot deformation (by alternating the strain). The deformation was not sufficient for the development of a massive recrystallization. Recrystallization only takes place at the boundaries of the large grains of the cast structure.

\subsection{Thermomechanical processing - cyclic loading and its influence on the microstructure}

The samples were subjected to the loading with cycles of tensile and compression deformation. The amount of deformation was increased in steps. It is

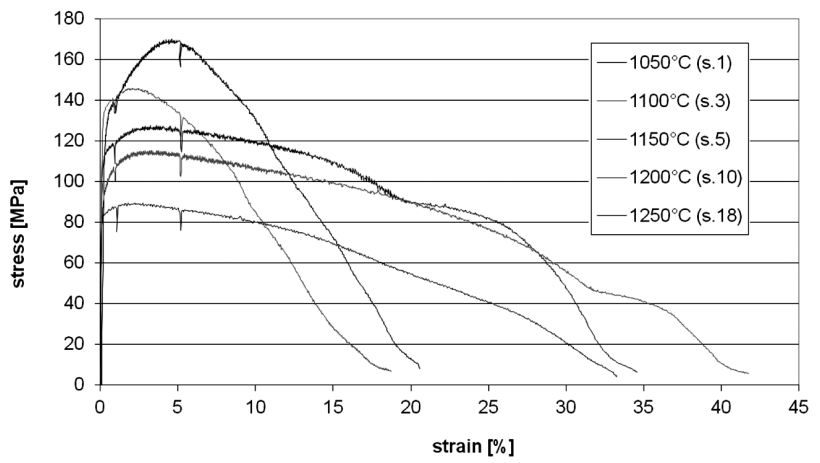

Figure 4: Stress-strain curves of the samples heated with resistance heating at $1050-1200{ }^{\circ} \mathrm{C}$

Slika 4: Krivulje napetost-raztezek za vzorce, ogrevane z uporovnim gretjem pri $1050-1200{ }^{\circ} \mathrm{C}$ 
evident that the increase in deformation (see Figure $\mathbf{6}$ for the applied deformation) led to an increase in the volume of recrystallized grains. At lower deformation, recrystallization occurs only at the boundaries of the grains, but with higher deformation, it extends into the grains (Figures 7 to 11).

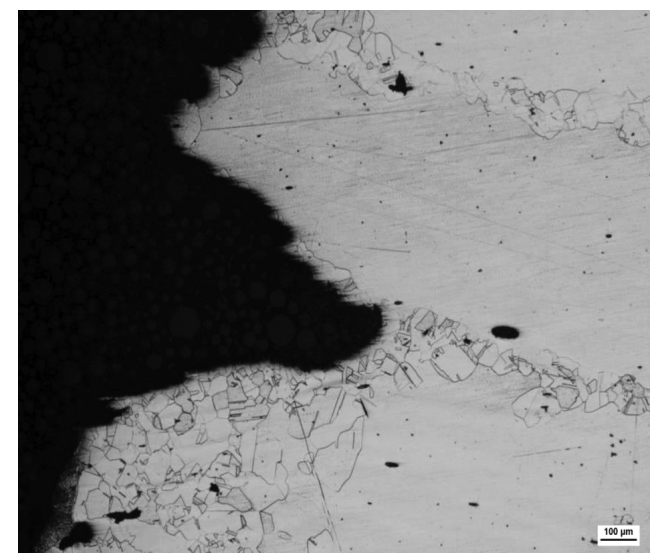

Figure 5: Microstructure of a sample near the fracture area after the tensile test performed at $1200{ }^{\circ} \mathrm{C}$

Slika 5: Mikrostruktura vzorca blizu preloma po nateznem preizkusu, izvršenem na $1200^{\circ} \mathrm{C}$

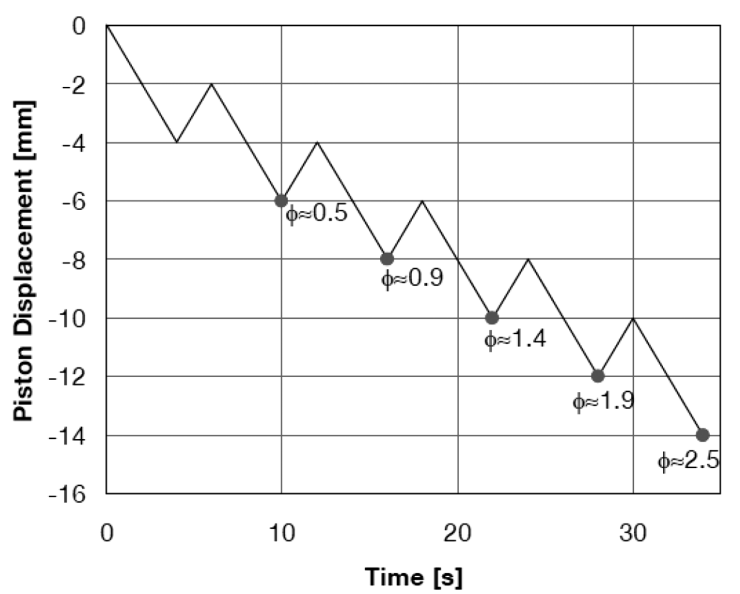

Figure 6: Deformation of particular samples

Slika 6: Deformacija posameznih vzorcev

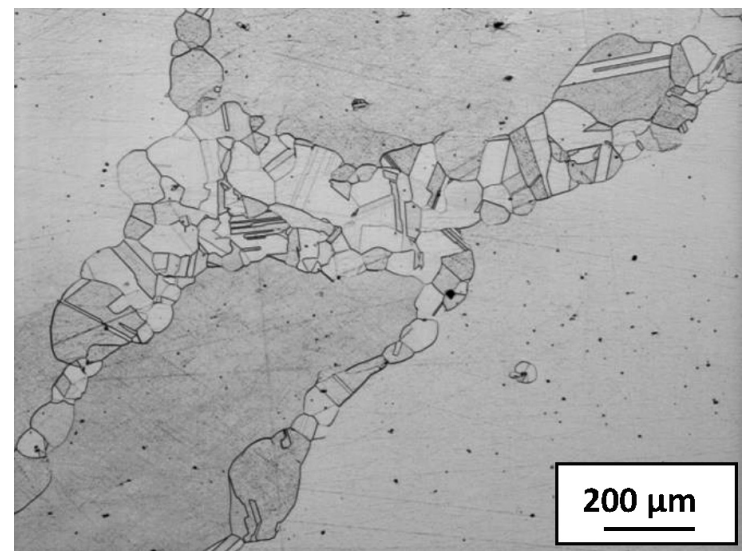

Figure 7: Microstructure after deformation $\Phi \approx 0.5$ Slika 7: Mikrostruktura po deformaciji $\Phi \approx 0,5$
A modelling of the graduation of embedded deformation was performed by means of the DEFORM software for a numerical simulation. Figure 12 shows the distribution of the effective strain in a sample after the last step.

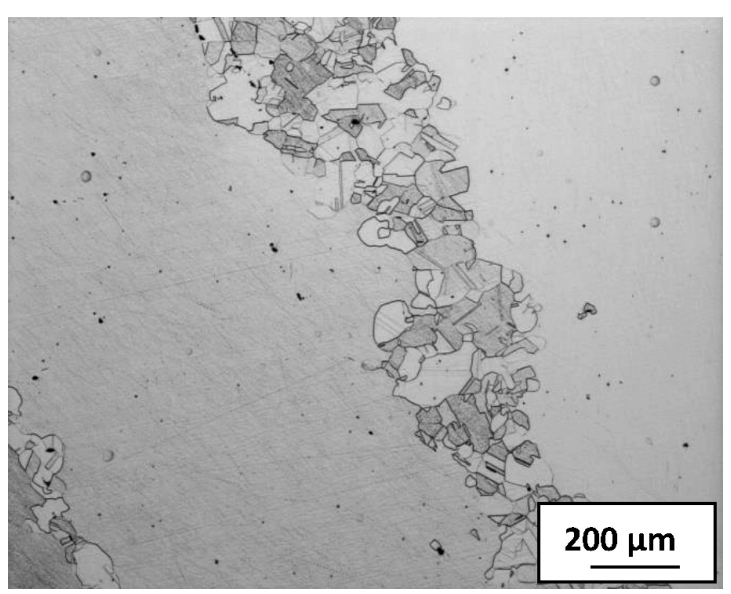

Figure 8: Microstructure after deformation $\Phi \approx 0.9$

Slika 8: Mikrostruktura po deformaciji $\Phi \approx 0,9$

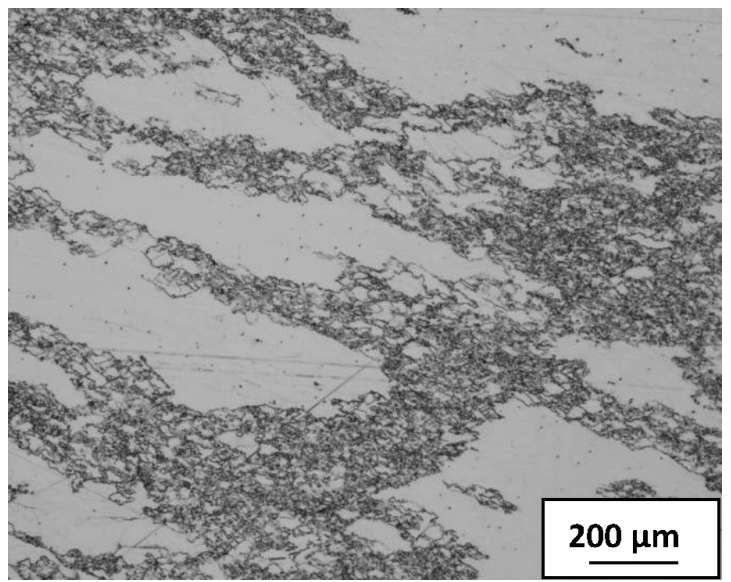

Figure 9: Microstructure after deformation $\Phi \approx 1.4$

Slika 9: Mikrostruktura po deformaciji $\Phi \approx 1,4$

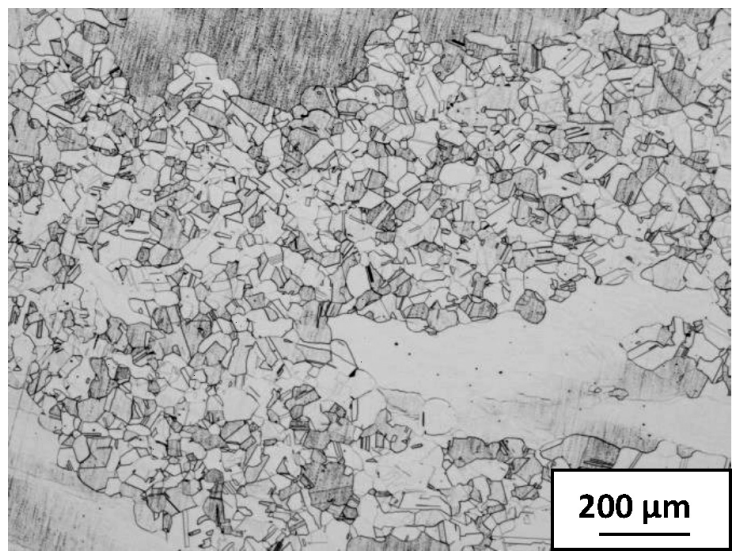

Figure 10: Microstructure after deformation $\Phi \approx 1.9$

Slika 10: Mikrostruktura po deformaciji $\Phi \approx 1,9$ 


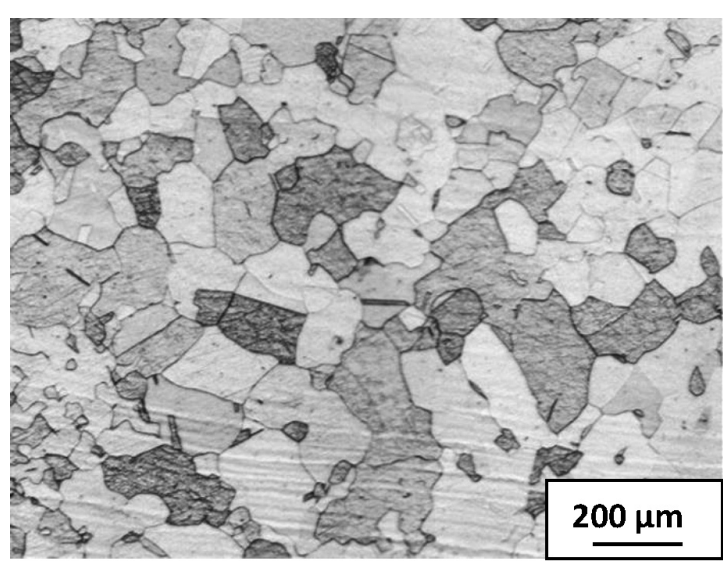

Figure 11: Microstructure after deformation $\Phi \approx 2.5$ Slika 11: Mikrostruktura po deformaciji $\Phi \approx 2,5$
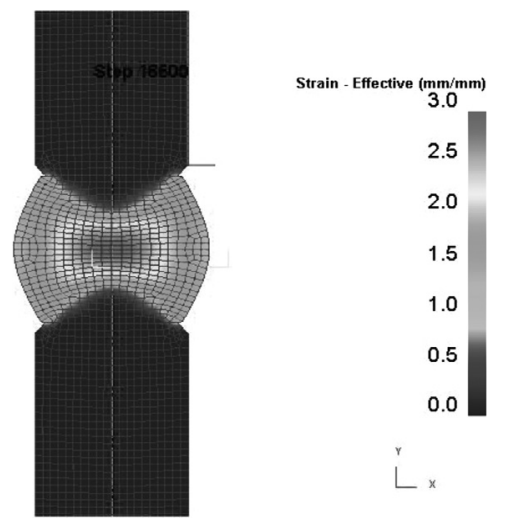

Figure 12: Effective-strain distribution in a sample after the last tensile-compression cycle. The calculated value of deformation is $\Phi$ $\approx 2.5$.

Slika 12: Razporeditev efektivnega raztezka $\mathrm{v}$ vzorcu po zadnjem natezno-tlačnem ciklu. Izračunana stopnja deformacije je $\Phi \approx 2,5$.

\subsection{Cold working of the samples prior to hot deforma- tion}

It was stated in the introduction that cold deformation of nickel superalloys promoted recrystallization during the following hot processing. An acceleration of the recrystallization process is obvious already in the case of a relatively small plastic deformation.

The volume fraction of the recrystallized microstructure with the highest cold deformation of a sample after the highest hot deformation is about $90 \% .^{13}$

\subsection{Experimental forging}

Experimental forging was carried out on a rectangular-shaped piece made from ingot. The dimensions of the sample were $45 \mathrm{~mm} \times 45 \mathrm{~mm} \times 125 \mathrm{~mm}$ (Figure 14a). The sample was gradually heated (Figure 14b) to a forging temperature of $1170{ }^{\circ} \mathrm{C}$.

Due to a rather quick natural cooling of the sample during the forging, only three reduction blows were applied in one forging step, immediately followed by
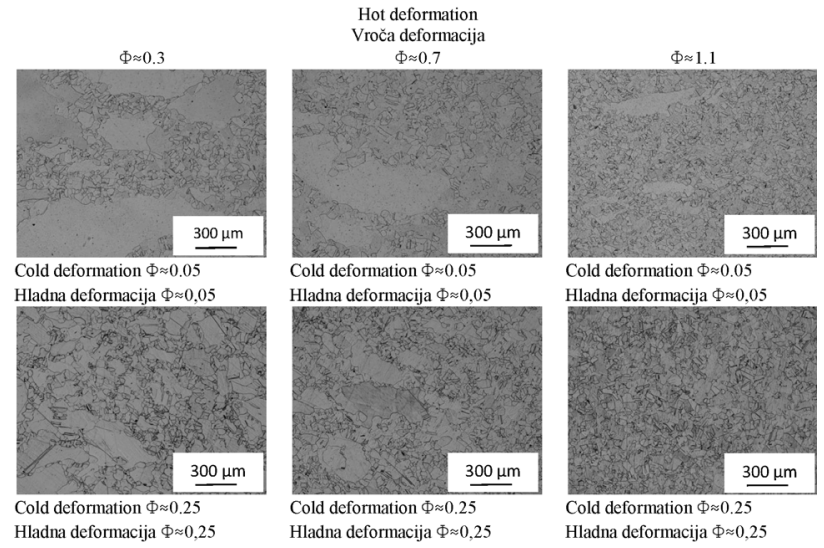

Figure 13: Influence of the size of cold and hot deformation on the share of the recrystallized structure

Slika 13: Vpliv stopnje hladne in vroče deformacije na delež rekristalizirane strukture

further reheating of the sample. The first forging operation before upsetting rounded the edges because sharp corners are usually the source of cracking. After that, the sample with dimensions of about $47 \mathrm{~mm}$ in diameter and about $150 \mathrm{~mm}$ in length was subjected to the upsetting to a height of about $90 \mathrm{~mm}$ and a diameter of about $60 \mathrm{~mm}$. The last forging operation was drawing. The final shape of the forged sample was rectangular, with two differently reduced parts (Figure 15). These two parts were subjected to a microstructure examination.

The microstructure of both parts shows a uniform distribution of the grains with no traces of the as-cast structure (Figures 16 and 17). Sample A shows a presence of small recrystallized grains $(5 \mu \mathrm{m}-10 \mu \mathrm{m})$ around the boundaries of larger grains (Figure 17b).

a)
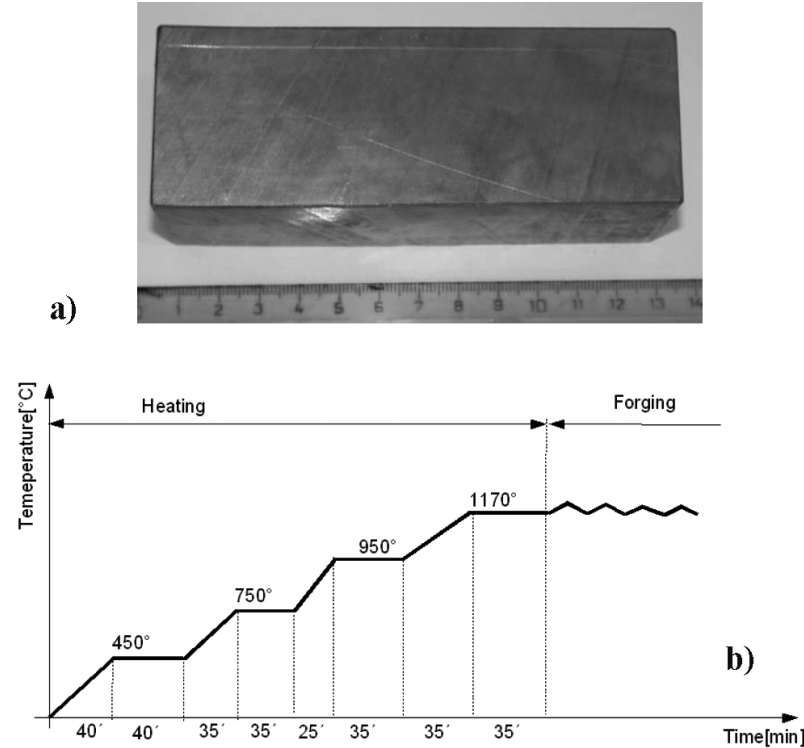

Figure 14: a) Sample for open-die forging on a hydraulic press, b) heating of the sample before forging

Slika 14: a) Vzorec za prosto kovanje na hidravlični preši, b) postopek ogrevanja vzorca pred kovanjem 


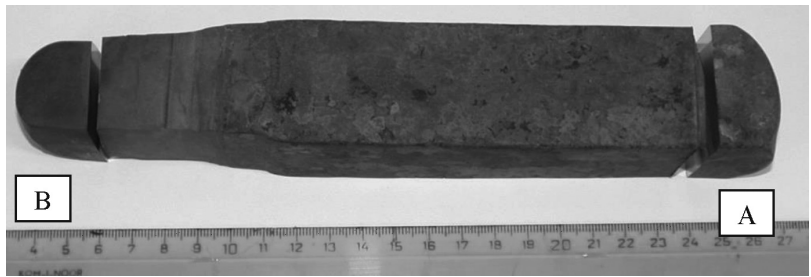

Figure 15: Forged sample after the final forging operation Slika 15: Kovan vzorec po končni operaciji kovanja

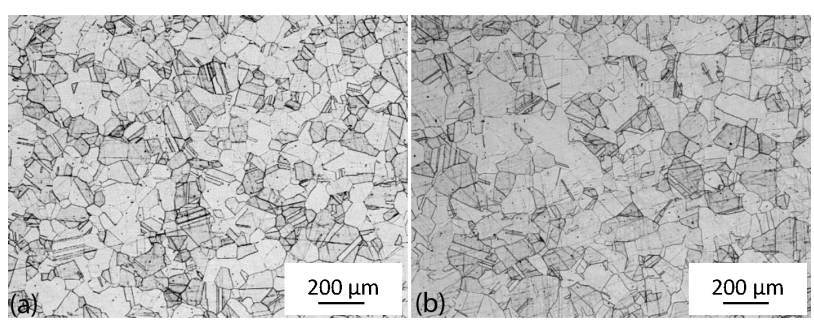

Figure 16: a) Microstructure of part B - near the surface, b) microstructure of part B - in the centre

Slika 16: a) Mikrostruktura v delu B - blizu površine, b) mikrostruktura v delu B - v sredini

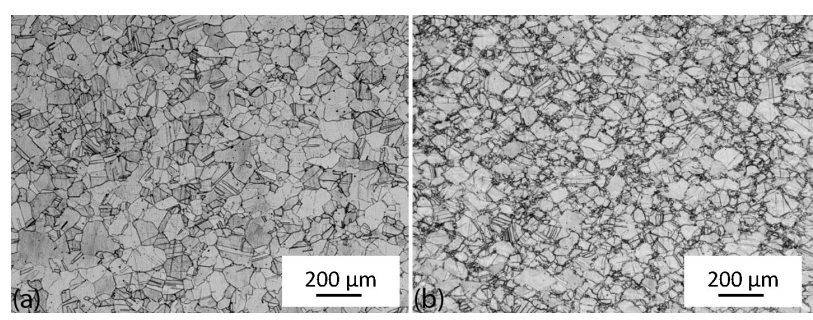

Figure 17: a) Microstructure of part A - near the surface, b) microstructure of part A - in the centre

Slika 17: a) Mikrostruktura v delu A - blizu površine, b) mikrostruktura v delu A - v sredini

The microstructure was also subjected to a grain-size measurement. The grain size was measured by means of image-analysis software NIS-Elements - module D.

a)
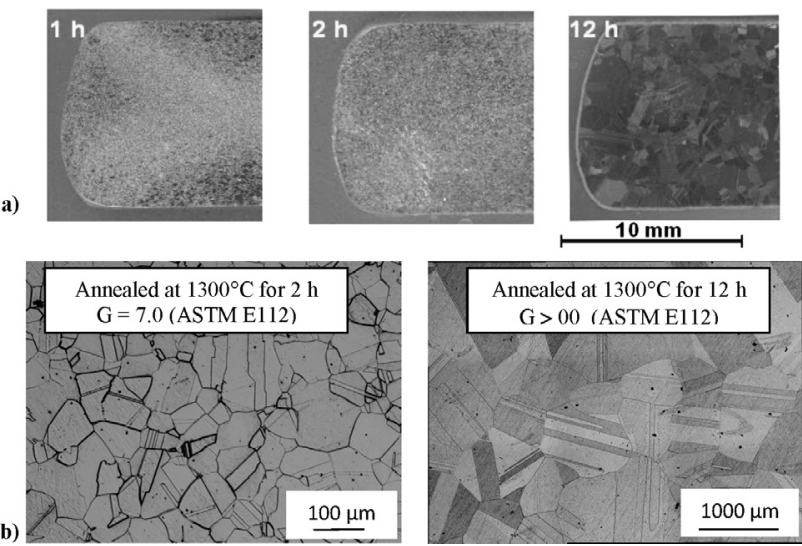

Figure 18: a) Grain growth after annealing at $1300{ }^{\circ} \mathrm{C}$ for $1 \mathrm{~h}, 2 \mathrm{~h}$ and $12 \mathrm{~h}, \mathrm{~b})$ comparison of the microstructures of the samples after annealing for $2 \mathrm{~h}$ and $12 \mathrm{~h}$ at $1300{ }^{\circ} \mathrm{C}$

Slika 18: a) Rast zrn po žarjenju na $1300{ }^{\circ} \mathrm{C} 1 \mathrm{~h}, 2 \mathrm{~h}$ in $12 \mathrm{~h}$, b) primerjava mikrostrukture vzorcev po žarjenju $2 \mathrm{~h}$ in $12 \mathrm{~h}$ na $1300^{\circ} \mathrm{C}$
Table 3: Grain size according to ASTM E 112

Tabela 3: Velikost zrn po ASTM E 112

\begin{tabular}{|c|c|c|}
\hline Sample & $\begin{array}{c}\text { Near the surface }-\mathrm{G} \\
\text { (ASTM E 112) }\end{array}$ & $\begin{array}{c}\text { Centre - G } \\
\text { (ASTM E 112) }\end{array}$ \\
\hline A & 5.5 & 5.0 \\
\hline B & 6.5 & 6.5 \\
\hline
\end{tabular}

\subsection{Further processing - annealing}

The obtained uniform microstructure had to be further processed with high-temperature annealing. It is necessary to obtain a uniform coarse-grained microstructure for ensuring good creep strength and crack-growth resistance. Figures $\mathbf{1 8 a}$ and $\mathbf{1 8 b}$ illustrate the grain growth after the annealing at $1300{ }^{\circ} \mathrm{C}$. Particular grain size shows Table 3.

\section{CONCLUSION}

The following facts were found during the research of the nickel-based-superalloy recrystallization behaviour:

- The warm strength of the monitored alloy is very high. Even at $1200{ }^{\circ} \mathrm{C}$ it significantly exceeds 100 $\mathrm{MPa}$. The ductility at the maximum stress is very low. After reaching the maximum stress, the material is further deformed but the first cracks start to arise. When the deformation continues a neck is not formed.

- It was found that the minimum deformation level for the start of the recrystallization during the hot working is $\Phi \approx 2.5$. Only such a high strain level ensures the recrystallization within the cast grains.

- The recrystallization process is significantly accelerated by the preceding cold forming. The structure was perfectly recrystallized after $\Phi \approx 0.25$ cold deformation followed by $\Phi \approx 1.1$ hot deformation.

- The microstructure examination after an intense experimental forging showed a good distribution of the recrystallized grains within the whole cross-section with respect to the compliance of the forging temperature.

- A coarse-grained microstructure for a good creep resistance can be obtained with the annealing at 1300 ${ }^{\circ} \mathrm{C}$ for $12 \mathrm{~h}$.

\section{Acknowledgments}

These results were created under the project entitled Development of West-Bohemian Centre of Materials and Metallurgy No.: LO1412, financed by the Ministry of Education, Youth and Sports of the Czech Republic.

\section{REFERENCES}

${ }^{1} \mathrm{~J}$. Malcharcziková et al., Influence of the hip process on the properties of as-cast Ni-based alloys, Mater. Tehnol., 49 (2015) 1, 15-18 
${ }^{2}$ M. J. Donachie, S. J. Donachie, Superalloys, A Technical Guide, The Materials Information Society, Materials Park, OH 2002

${ }^{3}$ Z. Nový et al., Recrystallization of Nickel Superalloys, 1st International Conference about Recent Trends in Structural Materials COMAT, Plzen 2010

${ }^{4}$ http://mragheb.com/NPRE\%20402\%20ME\%20405\%20Nuclear\%20 Power\%20Engineering/Fourth\%20Generation\%20Reactor\%20Conce pts.pdf

${ }^{5}$ P. Wangyao et al., Microstructure Development by Hot and Cold Working Processes in Nickel Based Alloy, Journal of Metals, Materials and Minerals, 13 (2003) 2, 33-43
${ }^{6}$ R. Jones, L. Jackmann, The Structural Evolution of Superalloy Ingots during Hot Working, Journal of Metals, 51 (1999) 1, 27-31

${ }^{7}$ V. Vrchovinsky et al., Effect of Final Cold Rolled Microstructure on Creep Deformation Behaviour on Nickel Base Alloy, Journal of Metals, Materials and Minerals, 15 (2005) 2, 57-68

${ }^{8}$ J. Džugan, Z. Nový, M. Sosnová, Fatigue life optimization of steel by thermomechanical treatment with the use of physical simulator, Advanced Materials Research, 264-265 (2011), 1725-1730, doi:10.4028/www.scientific.net/AMR.264-265.1725 